\title{
Characterization and comparison of mitochondrial DNAs and rRNAs from Penicillium urticae and $P$. chrysogenum
}

\author{
Junichi Sekiguchi,* Takeshi Ohsaki, Hiroki Yamamoto, KaZumichi KoIchi \\ and Toshio SHIDA
}

Department of Applied Biology, Faculty of Textile Science and Technology, Shinshu University, 3-15-1 Tokida, Ueda-shi, Nagano 386, Japan

(Received 8 August 1989; revised 3 November 1989 ; accepted 30 November. 1989)

\begin{abstract}
Mitochondrial DNA (mt DNA) from a patulin producer, Penicillium urticae (synonym $P$. griseofulvum), was $27.8 \mathrm{~kb} \pm 0.6 \mathrm{~kb}$ in size by electron microscopy and $27.2 \mathrm{~kb}$ by agarose gel electrophoresis. Restriction endonuclease maps for nine restriction enzymes were constructed, and eleven fragments which covered the total range of the mt DNA were cloned into the Escherichia coli plasmid vector pUC19. Southern analysis of the native genomes of $P$. urticae and $P$. chrysogenum with six of the cloned fragments as probes indicated similar genome arrangements as well as similar restriction maps. Both the large and small rRNA genes of $P$. urticae and $P$. chrysogenum were located on these restriction maps using Southern hybridization; and the result also supported the similar arrangement. Agarose/formaldehyde gel electrophoresis indicated that the small rRNA was 1.5 kb in size in both species; but, surprisingly, the large rRNA was $4.2 \mathrm{~kb}$ in size for $P$. urticae and $3.5 \mathrm{~kb}$ for $P$. chrysogenum. These sizes were, respectively, $1.1 \mathrm{~kb}$ and $0.4 \mathrm{~kb}$ larger than those from the very closely related Aspergillus nidulans.
\end{abstract}

\section{Introduction}

Penicillium chrysogenum and $P$. urticae (synonym $P$. griseofulvum) are industrially important filamentous fungi which produce penicillin and griseofulvin, respectively (Mantle, 1987). Moreover, $P$. urticae produces a mycotoxin, patulin, whose biosynthetic pathway is a model for 'polyketide' secondary metabolites (Sekiguchi \& Gaucher, 1978; Sekiguchi et al., 1983; Zamir, 1980). In spite of the importance of the genus Penicillium, there has been little research on its mitochondrial DNA (mt DNA): restriction maps and autonomously replicating segments (ARSs) of mt DNAs have been reported only for P. chrysogenum NRRL 1951 and BC2 (Smith et al., 1984; Saunders et al., 1984; Picknett et al., 1987; Stahl et al., 1987; Saunders \& Holt, 1987). These results suggested that $P$. chrysogenum mt DNA varies widely in size and genome order.

In the filamentous fungi, mt ribosomal RNAs (mt rRNAs) of Neurospora crassa (Green et al., 1981; Mahler, 1983) and Aspergillus nidulans (Köchel \& Küntzel, 1981, 1982; Dyson et al., 1989) have been extensively investigated, and recently the autocatalytic

Abbreviations: ARS, autonomously replicating segment; mt, mitochondrial. splicing mechanism of the large rRNA has been focused on (Garriga \& Lambowitz, 1984; Lambowitz, 1989). However, there are no reports about even the basic properties of rRNA from the genus Penicillium.

In this study, we characterized mt DNAs and rRNAs from $P$. urticae and $P$. chrysogenum and compared them by restriction mapping and Southern hybridization, and by localization of ARSs and rRNA genes.

\section{Methods}

Organisms and culture conditions. A patulin producer, Penicillium urticae NRRL 2159A, and two penicillin producers, Penicillium chrysogenum NRRL 1951 and IAM7119, were used. For slant cultures, glucose/yeast extract agar medium (Sekiguchi \& Gaucher, 1977) was used. For submerged cultures, MGG medium [ $50 \mathrm{~g}$ glycerol, $5 \mathrm{~g}$ yeast extract (Difco), $0.3 \mathrm{~g}$ glucose, $2 \mathrm{~g} \mathrm{KH}_{2} \mathrm{PO}_{4}, 1 \mathrm{~g} \mathrm{MgSO}_{4} .7 \mathrm{H}_{2} \mathrm{O}$ and $1 \mathrm{~g}$ $\left(\mathrm{NH}_{4}\right)_{2} \mathrm{SO}_{4}$ per litre (pH 6.5)] was used. A suspension of $P$. urticae conidia was inoculated into a 3 litre Sakaguchi flask containing 1 litre of MGG medium, followed by incubation at $28^{\circ} \mathrm{C}$ with shaking at 125 r.p.m. (incubator type $\mathrm{M}^{100^{D}}$; Taiyo). Escherichia coli JM109 recAl $\triangle\left(\right.$ lac-proAB) endAI gyrA96 thi-l hsdRI7 supE44 relAI $\lambda^{-}$ $\left[\mathrm{F}^{\prime}\right.$ : traD36 proAB lac/ $\left./ \mathrm{Z} \mathrm{AM} 15\right]$ (Yanisch-Perron et al., 1985) obtained from Takara was used as the recipient in cloning experiments. Saccharomyces cerevisiae SHY3 a ste-VC9 ura3-52 trp1-289 leu2-3 leu2112 his3- $\Delta 1$ ade1-101 can1-100 (Botstein et al., 1979) was used as the recipient in yeast transformation. $L B$ medium $[5 \mathrm{~g}$ yeast extract, $10 \mathrm{~g}$ polypeptone and $10 \mathrm{~g} \mathrm{NaCl}$ per litre $(\mathrm{pH} \mathrm{7.5)]} \mathrm{for} E$. coli culture, and 
YPD [ $10 \mathrm{~g}$ yeast extract, $20 \mathrm{~g}$ polypeptone and $20 \mathrm{~g}$ glucose per litre (pH 6.5)] and SD media $[6.7 \mathrm{~g}$ yeast nitrogen base w/o amino acids (Difco) and $20 \mathrm{~g}$ glucose per litre (pH 5.3)] for yeast culture were used. Plasmids pUC19 $\left(\mathrm{Ap}^{\mathrm{r}} \mathrm{Lac}^{+}\right)$(Yanisch-Perron et al., 1985) and YIp5 (Apr Tetr URA3) (Struhl et al., 1979) were used as vectors.

Isolation of $m t$ DNA. This was done basically as described by Stepien et al. (1978), except that the mycelia were disrupted in liquid nitrogen with an Ace homogenizer (Nissei). mt DNA was purified by DAPI (4',6-diamidino-2-phenylindole, Sigma)/CsCl or Hoechst 33258 (Sigma)/CsCl density-gradient ultracentrifugation as described by Cummings et al. (1979).

Isolation of total rRNAs and mt rRNAs. mt rRNAs were prepared as described by Wright et al. (1982). Total rRNA was isolated from homogenized mycelia. One-tenth volume of $6 \mathrm{M}$-urea solution containing $3 \mathrm{M}$ - $\mathrm{LiCl}$ was added to the homogenized solution and incubated at $0{ }^{\circ} \mathrm{C}$ overnight. After centrifugation at $16000 \mathrm{~g}$ for $20 \mathrm{~min}$ at $0{ }^{\circ} \mathrm{C}$, the pellet was resuspended in 10 vols $0.5 \%(\mathrm{w} / \mathrm{v}) \mathrm{SDS} / 10 \mathrm{mM}-\mathrm{Tris} / \mathrm{HCl}$ (pH 7.6) and extracted with chloroform/isoamyl alcohol $(24: 1, \mathrm{v} / \mathrm{v})$. The RNA was precipitated with ethanol and kept at $-80^{\circ} \mathrm{C}$ in $70 \%$ (v/v) ethanol.

Electron microscopy. Samples were prepared by a slight modification of the spontaneous-adsorption method (Lang \& Mitani, 1970). Plasmid pBR325 was used as a size reference.

Restriction enzyme analysis. Restriction endonucleases were purchased from Nippon Gene Co. and used according to the recommendations of the supplier.

Transformation of E. coli and S. cerevisiae. Transformation of E. coli JM109 and S. cerevisiae SHY3 was done as described by Silhavy et al. (1984) and Ito et al. (1983), respectively.

Cloning of $m t$ DNA. Standard cloning procedures were done as described by Maniatis et al. (1982). Eleven clones which covered the total range of mt DNA of $P$. urticae were constructed in $E$. coli JM109 as follows. Total mt DNA from $P$. urticae was digested with EcoRI or HindIII, and cloned into the corresponding site of pUC19. The resultant pME4 and pME5 contained the $3.0 \mathrm{~kb}$ and $2.0 \mathrm{~kb} E c o$ RI fragments of $P$. urticae mt DNA, respectively, and pMH2 and pMH7 contained the $4.7 \mathrm{~kb}$ and $1.4 \mathrm{~kb}$ HindIII fragments, respectively. For construction of pMH4, pMH5 and pMH6, the $2.45 \mathrm{~kb}$ and $1.9 \mathrm{~kb} H$ indIII fragments were separated by agarose gel electrophoresis and cloned into the HindIII site of pUC19. A NcoI site was found in the $1.9 \mathrm{~kb}$ HindIII fragment of pMH6, but not in that of pMH5. For pME22, mt DNA digested with EcoRI and PstI was cloned into the EcoRI and PstI sites of pUC19. pME22 contained the $1.9 \mathrm{~kb} E c o \mathrm{RI}-P s t \mathrm{I}$ insert. For pMB1, the $5.5 \mathrm{~kb}$ BamHI-Sall fragment separated by gel electrophoresis was cloned into the BamHI and Sall sites of pUC19. For PMP3, the $2.7 \mathrm{~kb}$ PstI fragment purified from PstI-digested mt DNA fragments was further digested with $S a c I$, and cloned into the PstI and SacI sites of pUC19. For pME12, the $8.4 \mathrm{~kb} E c o$ RI fragment purified from EcoRIdigested mt DNA fragments was further digested with BamHI, and cloned into the EcoRI and BamHI sites of pUC19. pMP3 and pME12 contained the $1.9 \mathrm{~kb}$ PstI-SacI and $3.4 \mathrm{~kb}$ EcoRI-BamHI fragments, respectively.

Gel electrophoresis of restriction fragments. Gel electrophoresis of restriction DNA fragments was done on submarine $1 \%(w / v)$ or $0 \cdot 3 \%$ agarose (type $\mathrm{LO}-3$ and $\mathrm{H}$, respectively; Nippon Gene) gels in a running buffer [0.04 $\mathrm{M}$-Tris/HCl (pH 8.1)/2 mM-EDTA] as described by Sharp et al. (1973).

Southern blot hybridization. The DNA probe was labelled with a nicktranslation kit (Nippon Gene) containing $[\alpha-32$ P]dATP (HAS). DNA fragments which had been separated by electrophoresis on $1 \%$ agarose

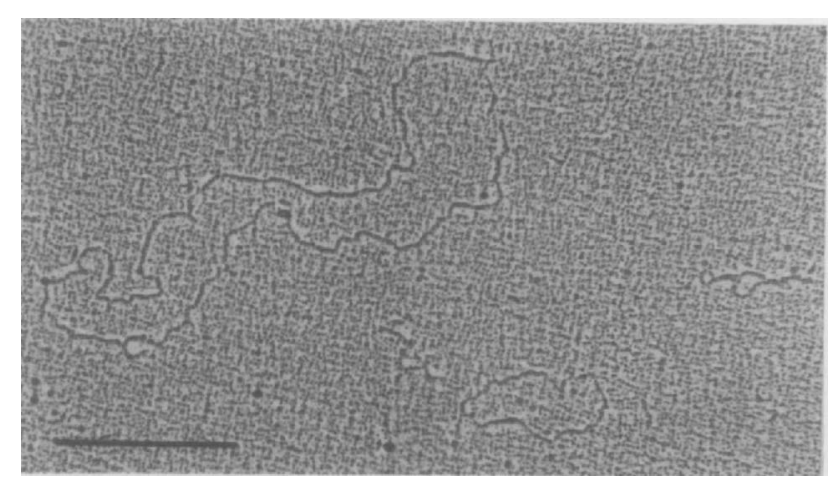

Fig. 1. Electron micrograph of $P$. urticae $\mathrm{mt}$ DNA and pBR325. One open circular $P$. urticae mt DNA, and one open and two closed circular pBR325 DNAs (5.996 kb), are shown. Bar, $1 \mu \mathrm{m}$.

gel were transferred to a nylon membrane (magnagraph nylon; Micron Separations Inc.) by the method of Southern (1975). Hybridization was done basically as described by Maniatis et al. (1982).

RNA manipulations. Molecular size measurements of RNA by gel electrophoresis were done as described by Lehrach et al. (1977) with minor modifications. RNA samples were dissolved in buffered formaldehyde solution $[50 \%(v / v)$ formamide, $17.5 \%(v / v)$ formaldehyde, MOPS buffer (0.02 M-MOPS (pH 7.0)/5 mM-sodium acetate/ $1 \mathrm{~mm}$-EDTA)], heated at $90^{\circ} \mathrm{C}$ for $2 \mathrm{~min}$, and rapidly cooled to room temperature. Two microlitres of loading buffer $[50 \%(\mathrm{v} / \mathrm{v})$ glycerol/ $1 \mathrm{~mm}-\mathrm{EDTA} / 0.4 \%$ (w/v) bromophenol blue $/ 0 \cdot 4 \%$ (w/v) xylenecyanol FF] was added to the RNA solution $(20 \mu \mathrm{l})$. The RNA samples were put onto agarose/formaldehyde gels ( $1 \%$ agarose/2.2 M-formaldehyde/ MOPS buffer) and electrophoresis was done in the MOPS buffer at $100 \mathrm{~V}$ for $6 \mathrm{~h}$. RNA Molecular Weight Marker II (Boehringer) was used as a size reference. rRNA probe was extracted from the gels by electroelution (Maniatis et al., 1982) concentrated through NENSORB20 (Dupont), and labelled at the $5^{\prime}$ terminal with $\left[\gamma^{-32}\right.$ P]ATP (HAS) and T4 polynucleotide kinase (Takara) after dephosphorylation (Maxam \& Gilbert, 1980).

\section{Results}

\section{Electron microscopy of mt DNA of P. urticae $2159 \mathrm{~A}$}

mt DNA from $P$. urticae 2159A was purified from the upper band after DAPI/CsCl or Hoechst $33258 / \mathrm{CsCl}$ ultracentrifugation. An electron micrograph of the $\mathrm{mt}$ DNA and pBR325 (5.996 kb; as an internal standard) is shown in Fig. 1. A mt DNA solution prepared by mild disruption of mycelia ( $30 \mathrm{~s}$ homogenization) contained an increased number of circular molecules and moderately degraded size-heterogeneous linear fragments. A histogram of the contour lengths of the circular molecules showed two peaks, corresponding to pBR325 $(2 \cdot 0 \pm 0 \cdot 1 \mu \mathrm{m}, n=41)$ and $\mathrm{mt}$ DNA from $P$. urticae $(9 \cdot 24 \pm 0 \cdot 20 \mu \mathrm{m}, n=15)$, respectively. From these results, the molecular size of mt DNA was $27.7 \pm 0.6 \mathrm{~kb}$. 
Table 1. Sizes $(k b)$ of restriction fragments of $m t$ DNAs

\begin{tabular}{|c|c|c|c|c|c|c|c|}
\hline \multirow{2}{*}{$\begin{array}{l}\text { Fragment } \\
\text { no. }\end{array}$} & \multicolumn{4}{|c|}{ P. urticae $2159 A^{*}$} & \multicolumn{3}{|c|}{ P. chrysogenum $1951 \dagger$} \\
\hline & NotI & PstI & EcoRI & HindIII & PstI & EcoRI & HindIII \\
\hline 1 & 18.0 & 14.0 & 8.4 & $10 \cdot 5$ & $23 \cdot 2$ & 7.9 & $6 \cdot 1$ \\
\hline 2 & 9.4 & 10.5 & 7.0 & 4.7 & $2 \cdot 7$ & 6.7 & 4.6 \\
\hline 3 & & 2.7 & 6.8 & $3 \cdot 4$ & & 6.4 & $4 \cdot 3$ \\
\hline 4 & & & 3.0 & $2 \cdot 45$ & & $2 \cdot 5$ & $2 \cdot 8$ \\
\hline 5 & & & $2 \cdot 0$ & $1.9 \ddagger$ & & $2 \cdot 3$ & $2 \cdot 4$ \\
\hline 6 & & & & 1.97 & & & $1.7 \S$ \\
\hline 7 & & & & 1.36 & & & $1.7 \S$ \\
\hline 8 & & & & 0.90 & & & 1.25 \\
\hline 9 & & & & & & & 0.87 \\
\hline Total: & $27 \cdot 4$ & $27 \cdot 2$ & $27 \cdot 2$ & $27 \cdot 1$ & $25 \cdot 9$ & $25 \cdot 8$ & $25 \cdot 7$ \\
\hline
\end{tabular}

* Digestion with AvaI, BamHI, Sall, SacI or XhoI produced a $27.2 \mathrm{~kb}$ fragment.

$\dagger$ Digestion with NcoI, AvaI, BamHI or Sall produced a $25.8 \mathrm{~kb}$ fragment. The digestion pattern of mt DNA from P. chrysogenum 7119 with PstI, EcoRI, HindIII or EcoRI + HindIII was identical to that of $P$. chrysogenum 1951.

$\ddagger$ Fragment nos 5 and 6 were overlapped.

§ Fragment nos 6 and 7 were overlapped.

Restriction enzyme analysis of $m t$ DNAs from $P$. urticae 2159A, and P. chrysogenum 1951 and 7119

Table 1 shows the DNA fragment sizes of $P$. urticae and $P$. chrysogenum generated by the restriction endonucleases used in this study. For accurate measurement of the large fragment sizes, $0.3 \%$ agarose gels were used. The mean total genome size of $P$. urticae mt DNA calculated from the fragment sizes listed for all enzymes was $27.2 \mathrm{~kb}$, which agrees excellently with the size calculated from electron microscopy. The total genome sizes of $P$. chrysogenum 1951 and $7119 \mathrm{mt}$ DNAs were $25.8 \mathrm{~kb}$, a value similar to that of $27.1 \mathrm{~kb}$ obtained by Stahl et al. (1987) for $P$. chrysogenum BC2. However, the size of $P$. chrysogenum $1951 \mathrm{mt}$ DNA was quite different from the earlier report of $49 \mathrm{~kb}$ by Smith et al. (1984). By single, double and triple digestion and agarose gel electrophoresis of native mt DNA (some of the data are shown in Figs 3 and 6), restriction maps of $P$. urticae 2159A and $P$. chrysogenum 1951 were constructed (Fig. 2). The pattern of $P$. chrysogenum 1951 was identical to that of $P$. chrysogenum 7119 and very similar to that of $P$. chrysogenum BC2 except for one extra HindIII site (Stahl et al., 1987; Fig. 2). Comparison of the restriction maps of $P$. urticae and $P$. chrysogenum indicates that the $\mathrm{mt}$ DNA molecules of these species resemble each other (Fig. 2). The sizes of $\mathrm{mt}$ DNAs from the genus Penicillium are similar to those of $A$. nidulans $(31.5 \mathrm{~kb})$ and Cephalosporium acremonium $(27 \mathrm{~kb})$, but much smaller than those of other ascomycete genera (Grossman \& Hudspeth, 1985).
Cloning of mt DNA fragments from $P$. urticae

$P$. urticae mt DNA fragments were cloned as described in Methods. Fragment identities were confirmed by agarose gel electrophoresis and Southern hybridization (data not shown). Fig. 2 shows clones containing $\mathrm{mt}$ DNA fragments. The eleven clones covered the total range of mt DNA of $P$. urticae.

Southern hybridization of $m t D N A$ from $P$. chrysogenum 1951 with the cloned $P$. urticae mt DNA fragments as probes

To compare the genome order of mt DNA between $P$. urticae and $P$. chrysogenum, $P$. chrysogenum $1951 \mathrm{mt}$ DNA digested with EcoRI, HindIII, or EcoRI + HindIII was separated by agarose gel electrophoresis, and Southern transfer and hybridization were done with pME4, pME5, pME12, pMH2, pMH4 and pMB1 as probes. The results are shown in Figs 3 and 4, and summarized in Fig. 2. The probe pME4 hybridized to the EH6 fragment and weakly to the EH3 fragment (fifth and third bands from the top in lane 3, respectively) (Fig. 3 , lane 6). The probes pME5, pMH2, and pME12 hybridized to EH3, EH2 and EH5 (third, second, and fourth bands from the top in lane 3, respectively) (Fig. 3, lanes 9, 12 and 15). The probes pMB1 and pMH4 hybridized to EH1 and EH4 (first and third bands, respectively, from the top in Fig. 4, lane 4) (Fig. 4, lanes 7 and 10). Thus the mt DNA fragments of $P$. urticae hybridized at similar regions of mt DNA of $P$. 
I
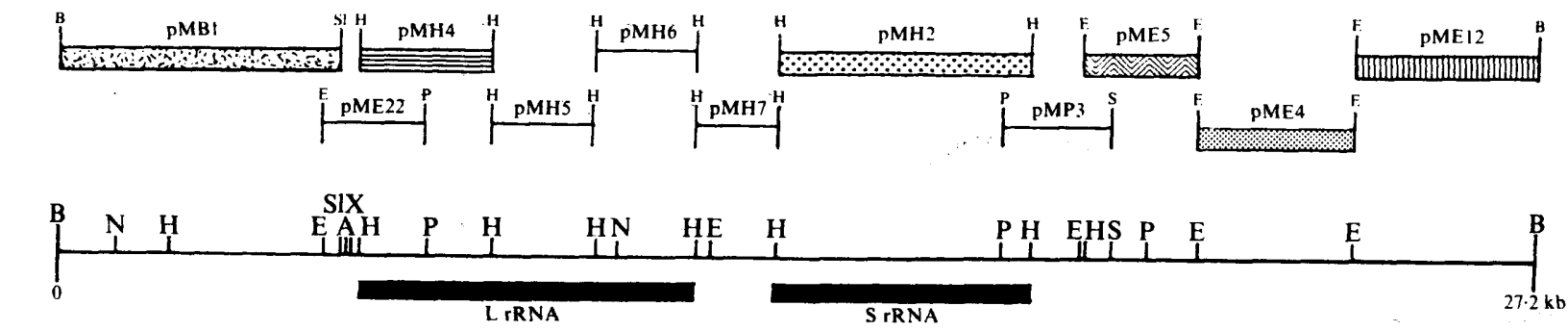

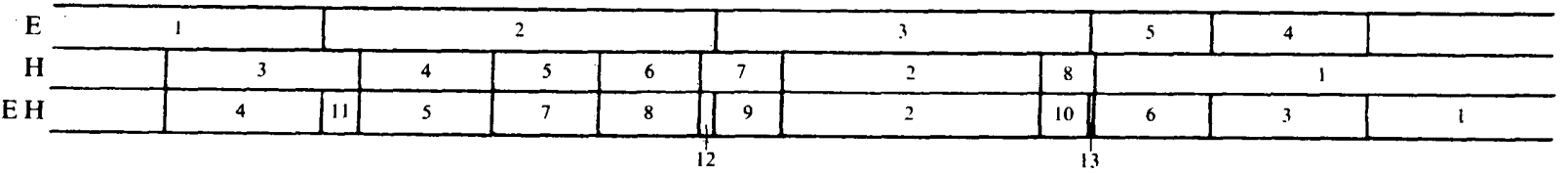

II

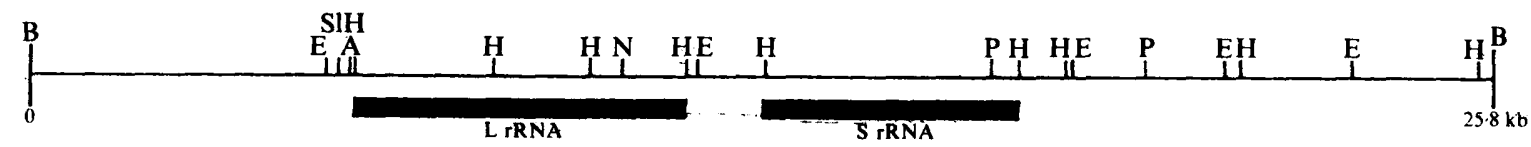

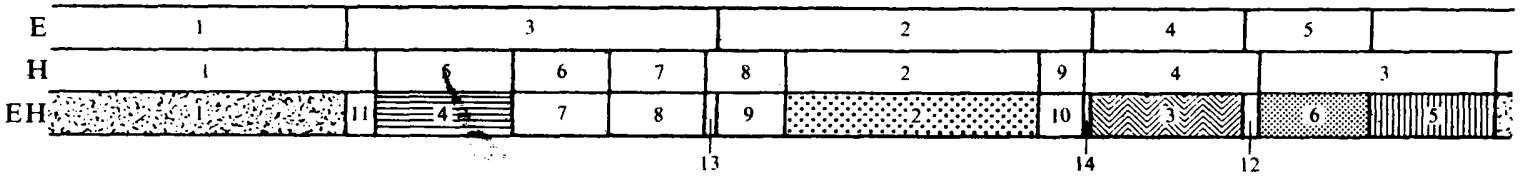

III

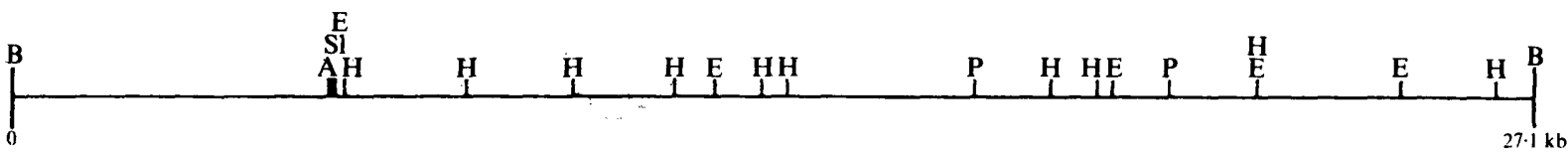

Fig. 2. Restriction maps and/or cloned fragments of mt DNAs from $P$. urticae and $P$. chrysogenum. $1, P$. urticae 2159A; II, $P$. chrysogenum 1951 and 7119; III, $P$. chrysogenum BC2 (linearized map at BamHI site; Stahl et al., 1987). Clone designation and the inserted fragments of $P$. urticae 2159A mt DNA are shown above the map of I. Numbers of EcoRI (E) and HindIII (H) fragments shown in blocks correspond to the numbers in Table 1. Fragment sizes from the larger fragment of $P$. urticae mt DNA digested with $E c o R I+H i n d I I I$ are 5.5, 4.7, 3.0, 2.9, 2.45, 2.0, 1.9, 1.9, 1.12, 0.93, 0.54 and $0.24 \mathrm{~kb}$, and the fragments are designated as EH1 to EH12, respectively (1). The size of the smallest fragment (EH13) of $P$. urticae was not measured. Fragment sizes of $P$. chrysogenum 1951 and $7119 \mathrm{mt}$ DNA digested with $E c o \mathrm{RI}+\mathrm{HindIII}$ are 5.6, 4.6, 2.5, 2.4, 2.3, 2.0, 1.7, 1.7, 1.15, 0.87, 0.53, 0.29, 0.24 and 0.17 kb, and the fragments are designated as EH1 to EH14, respectively (II). Thick lines represent the defined coding regions of mt large (L) rRNA and small (S) rRNA. For P. chrysogenum mt DNA digested with EcoRI + HindIII, regions homologous to the cloned fragments are shown by the appropriate shading. A, AvaI; B, BamHI; E, EcoRI; H, HindIII; N, NcoI; P, PstI; S, SacI; Sl, SalI; X, XbaI. The NcoI site(s) is undetermined for the mt DNA of $P$. chrysogenum BC2.

chrysogenum 1951 (Fig. 2). These results indicate a similar genome order in these two species.

\section{ARSs of mt DNA from P. urticae}

mt DNA from $P$. chrysogenum BC2 had at, least three regions of autonomous replication function (ARSs) in $S$. cerevisiae (E4, E5, and $\mathrm{H} 1$ in Fig. 2 II; Stahl et al., 1987). Fragments estimated from the restriction map to contain the corresponding region were tested for ARS activity. The $2.0 \mathrm{~kb}$ EcoRI fragment (E5) of pME5 and the $3.4 \mathrm{~kb}$ EcoRI-BamHI fragment (part of E1) of pME12 of mt DNA from $P$. urticae were subcloned to the EcoRI site, and the EcoRI and BamHI sites, respectively, of YIp5, which lacks a replication origin in $S$. cerevisiae. The new plasmids were designated as YIp5E5 and YIp5E12, respectively. These plasmids were used to transform $S$. cerevisiae SHY3 by the method with alkali cations (Ito $e t$ al., 1983). Ura ${ }^{+}$transformants were obtained with YIp5E5 and YIp5E12 at frequencies of $7.4 \times 10^{2}$ and $2.3 \times 10^{2}$ per $\mu \mathrm{g}$ DNA, respectively, but no transformants were obtained with control YIp5 $\left(<1 \mu \mathrm{g}^{-1}\right)$. To determine whether the plasmids had been modified, four transformants were randomly chosen from each transformation and used for mini-prep plasmid isolation (Hoffman \& Winston, 1987). The lysates were used for transformation of $E$. coli JM109: considerable numbers of transformants were obtained for all samples. Plasmid isolation and restriction enzyme analysis showed the presence of the original plasmid (YIp5E5 or YIp5E12) in 

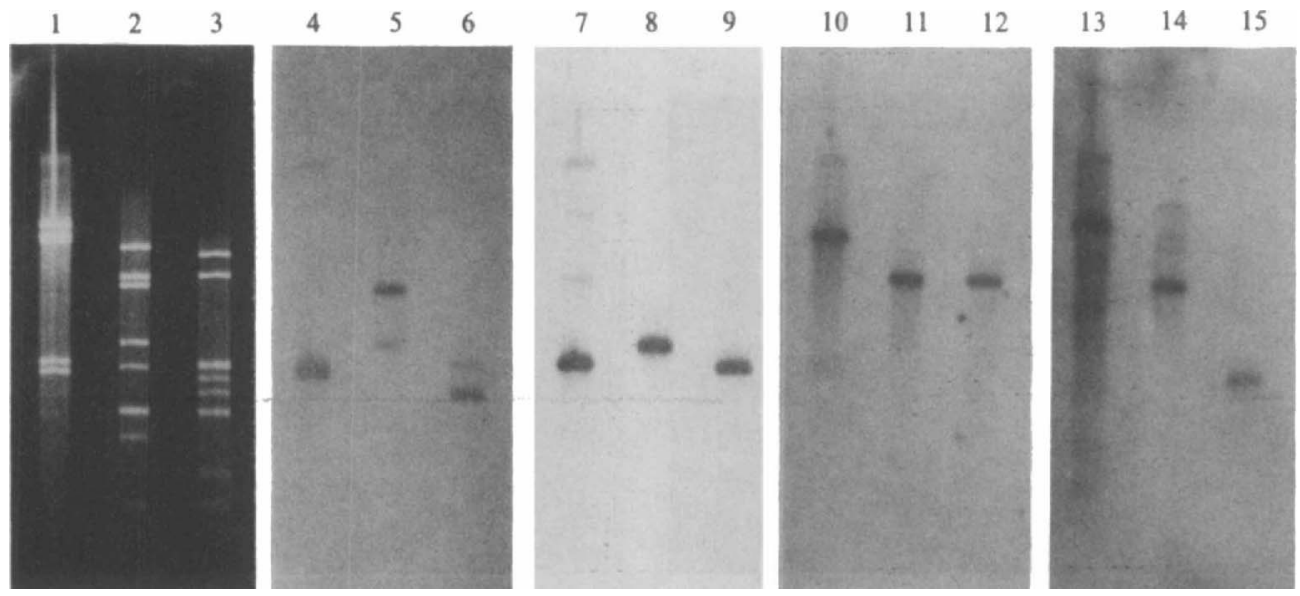

Fig. 3. Southern hybridization analysis of mt DNA from $P$. chrysogenum 1951 . Lanes 1 to 3 are $1 \%$ agarose gel electrophoresis of $P$. chrysogenum $1951 \mathrm{mt}$ DNA digested with EcoRI, HindIII, and EcoRI + HindIII, respectively. Lanes 4, 7, 10 and 13 are Southern hybridization of lane 1 ; lanes 5,8,11 and 14 are of lane 2 ; and lanes $6,9,12$ and 15 are of lane 3. Probes for lanes 4 to 6,7 to 9,10 to 12 and 13 to 15 are pME4, pME5, pMH2 and pME12, respectively. Migration is from top to bottom. The transfer membrane was repeatedly used after washing with renaturation buffer $(\mathrm{RB})[\times 20 \mathrm{RB}: 50 \mathrm{mM}-\mathrm{Tris} / \mathrm{HCl}(\mathrm{pH} 8.0), 2 \mathrm{mM}-\mathrm{EDTA}, 0.5 \%(\mathrm{w} / \mathrm{v})$ sodium pyrophosphate, $0.02 \%$. w/v) bovine serum albumin, $0.02 \%(\mathrm{w} / \mathrm{v})$ Ficoll and $0.02 \%(\mathrm{w} / \mathrm{v})$ polyvinylpyrrolidone] at $65{ }^{\circ} \mathrm{C}$ for $3 \mathrm{~h}$. The sixth band from the top in lane 2 contains the overlapped fragments $\mathrm{H} 6$ and $\mathrm{H} 7$. The third and sixth bands in lane 3 contain the overlapped fragments EH3 and EH4, and EH7 and EH8, respectively. Fragments smaller than $0.3 \mathrm{~kb}$ were not analysed by Southern hybridization. Hybridized fragments are band 5 (E5) in lane 4, band 3 (H3) and band 4 (H4, weak) in lane 5, band 3 (EH3, weak) and band 5 (EH6) in lane 6, band 4 (E4) in lane 7, band 4 (H4) in lane 8, band $3(\mathrm{EH} 3)$ in lane 9 , band 2 (E2) in lane 10, band $2(\mathrm{H} 2$ ) in lane 11, band 2 (EH2) in lane 12, band 1 (E1) in lane 13, band 3 (H3) in lane 14 , and band 4 (EH5) in lane 15.

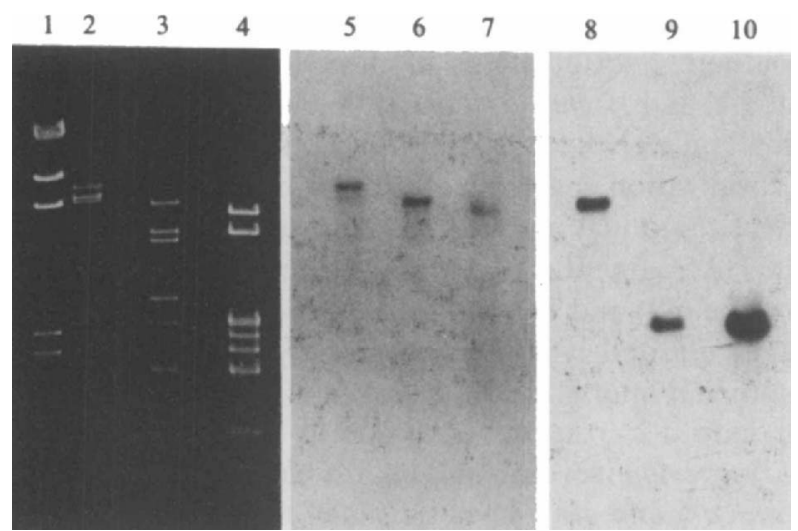

Fig. 4. Southern hybridization analysis of $m t$ DNA from $P$. chrysogenum 1951. Lanes 2 to 4 correspond to lanes 1 to 3 in Fig. 3, respectively. Lanes 5 and 8 are Southern hybridizations of lane 2 ; lanes 6 and 9 are of lane 3 , and lanes 7 and 10 are of lane 4. Lane 1 is $\lambda$ HindIII fragments. Probes for lanes 5 to 7 and 8 to 10 are pMB1 and pMH4, respectively. Hybridized fragments are band 1 (E1) in lane 5 , band 1 (H1) in lane 6, band 1 (EHI) in lane 7, band 3 (E3) in lane 8, band 5 (H5) in lane 9, and band 3 (EH4) in lane 10.

the $E$. coli transformants (data not shown). These results indicated that ARS activities in mt DNA of $P$. urticae are located in the $2.0 \mathrm{~kb}$. EcoRI fragment (E5) which is homologous to E4 of $P$. chrysogenum (Fig. 2, II), and in

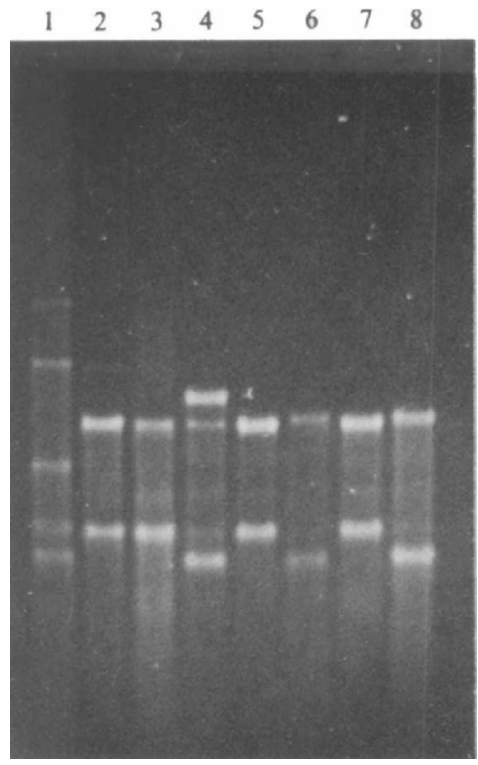

Fig. 5. Electrophoresis of $\mathrm{mt}$ rRNAs and cytosol rRNAs from $P$. urticae and $P$. chrysogenum on $1 \%$ agarose gel containing $2.2 \mathrm{M}-$ formaldehyde. Lane 1, RNA size markers $(7 \cdot 4,5 \cdot 3,2 \cdot 8,1.9$ and $1.6 \mathrm{~kb}$; Boehringer). Lane 2, cytosol rRNAs from $S$. cerevisiae AH22, as a control. Lanes 3, 5 and 7, cytosol rRNAs of $P$. urticae 2159A, $P$. chrysogenum 7119 and 1951 , rspectively. Lanes 4, 6 and 8, mt rRNAs of $P$. urticae 2159A, $P$. chrysogenum 7119 and 1951, respectively. Weak bands $(3.4$ and $1.8 \mathrm{~kb})$ in lane 4 are contaminants of cytosol rRNAs. Migration is from top to bottom. 
(a)

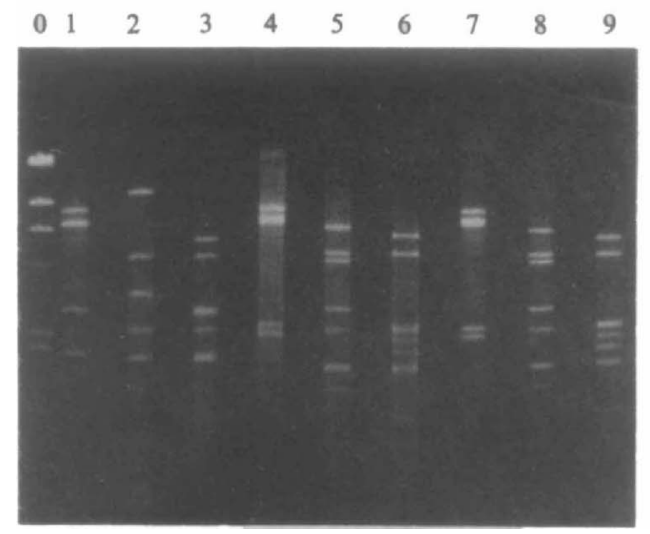

(b)

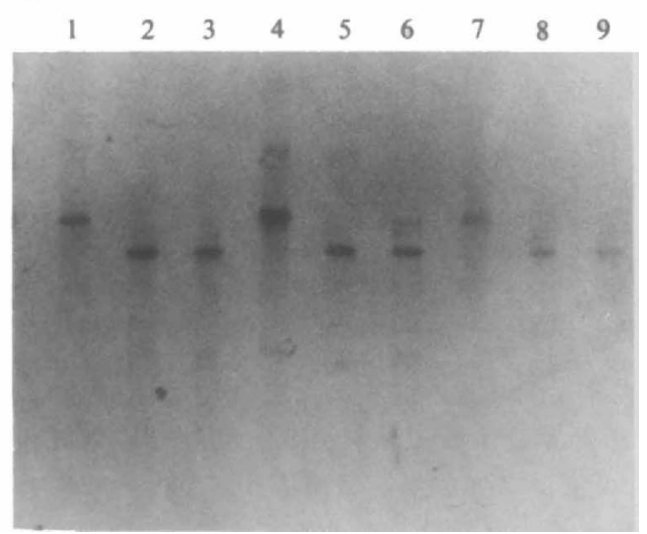

Fig. 6. Agarose gel electrophoresis of restriction enzyme digested mt DNA fragments from $P$. urticae and $P$. chrysogenum (a) and Southern hybridization analysis with small $\mathrm{mt}$ rRNA as a probe $(b)$. Small $\mathrm{mt}$ rRNA was separated on agarose/formamide gel, and extracted and purified as described in Methods. Labelling of small mt rRNA was performed with T4 polynucleotide kinase and [ $\gamma$ ${ }^{32}$ P]ATP, after the removal of $5^{\prime}$ phosphate by treatment with calf intestine alkaline phosphatase. Southern transfer and hybridization were done as described in Methods and the results are shown in (b). Lane 0 is HindIII-digested $\lambda$ DNA, lanes 1, 4 and 7 are EcoRIdigested mt DNAs, lanes 2, 5 and 8 are HindIII-digested $\mathrm{mt}$ DNAs, and lanes 3,6 and 9 are EcoRI- and HindIII-double-digested mt DNAs. Lanes 1 to 3, 4 to 6, and 7 to 9 are mt DNAs from $P$. urticae $2159 \mathrm{~A}, P$. chrysogenum 7119 and $P$. chrysogenum 1951 , respectively. Lanes 1 to 9 in (a) correspond to lanes 1 to 9 in $(b)$. The third and fifth bands in lane 3 contain overlapped fragments (EH3 and EH4, and EH6, EH7 and EH8, respectively). Overlapped fragments for $P$. chrysogenum shown in lanes 5, 6, 8, and 9 are explained in the legend of Fig. 3.

the 3:4 kb EcoRI-BamHI fragment (part of E1). These ARSs were defined as putative replicons only for yeast, but they may be functional in homologous and heterologous systems as described by Tudzynski \& Esser (1985).

\section{Molecular sizes of mitochondrial $r R N A$ large and small fragments from $P$. urticae and $P$. chrysogenum strains}

Fig. 5 shows the agarose/formaldehyde gel electrophoresis of mitochondrial and cytosol rRNAs from $P$. urticae and two strains of $P$. chrysogenum. The molecular sizes of large and small cytosol rRNAs were 3.4 and $1.8 \mathrm{~kb}$, respectively, among the three penicillia and $S$. cerevisiae. For mitochondrial rRNAs, the size of the small subunit was $1.5 \mathrm{~kb}$ among the three penicillia, but the larger subunit was $4.2 \mathrm{~kb}$ in $P$. urticae, and $3.5 \mathrm{~kb}$ in $P$. chrysogenum. This surprising result is not caused by an artifact of isolation or electrophoresis. Three repeated experiments supported the above results. The size of cytosol rRNAs in $S$. cerevisiae was identical to the published results (Georgiev et al., 1981; Rubtsov et al., 1980). Moreover, electrophoresis on glyoxal gels (Maniatis et al., 1982) also supported the above sizes (data not shown). Since the similarity in genome orders and restriction maps of mt DNA between $P$. urticae and $P$. chrysogenum suggests high conservation of $\mathrm{mt}$ DNA, it is interesting that the size of the rRNA large subunit was very different between them.

\section{Location of large and small $m t r R N A$ genes}

Southern hybridizations of $\mathrm{mt}$ DNAs from $P$. urticae 2159A, and P. chrysogenum 7119 and 1951, with labelled small mt rRNA from $P$. urticae are shown in Fig. 6. The hybridization pattern of $P$. chrysogenum 1951 was identical to that of 7119. The small rRNA hybridized to the $\mathrm{H} 2$ fragment of $P$. urticae (second band from the top in lane $a-2$ ) and $\mathrm{H} 2$ of $P$. chrysogenum (second band in lanes $a-5$ and $a-8$ ). However, the probe hybridized to neither $\mathrm{H} 7$ nor $\mathrm{H} 8$ of $P$. urticae (sixth and seventh bands in lane $a-2$, respectively), nor to $\mathrm{H} 8$ or $\mathrm{H} 9$ from $P$. chrysogenum (seventh and eighth bands, respectively, in lanes $a-5$ and $a-8$ ). Thus the small mt RNA genes of $P$. urticae and $P$. chrysogenum were confined to the $4.7 \mathrm{~kb}$ fragment (H2 and EH2 in Fig. 2, I) and $4.6 \mathrm{~kb}$ fragment (H2 and EH2 in Fig. 2, II), respectively.

The large rRNA hybridized to the $\mathrm{H} 5$ and/or $\mathrm{H} 6$ fragment(s) $(1.9 \mathrm{~kb}$; fifth band from the top in Fig. $7 a$, lane 2) and weakly to $\mathrm{H} 4$ (fourth band in lane $a-2$ ) from $P$. urticae. When the HindIII fragments were digested with $N c o$ I, the probe hybridized to $\mathrm{H} 5$, and also to the $1.4 \mathrm{~kb}$ and $0.5 \mathrm{~kb}$ HindIII-NcoI fragments derived from H6. Hybridization to two PstI fragments (14.0 and $10.5 \mathrm{~kb}$ ) was also observed (data not shown). For $P$. chrysogenum, the large rRNA also hybridized to H6 and $\mathrm{H} 7$ (sixth band in lanes 5 and 8 ; unpublished result) and weakly to $\mathrm{H} 5$ (fifth band). Thus the large mt rRNA genes 
(a)

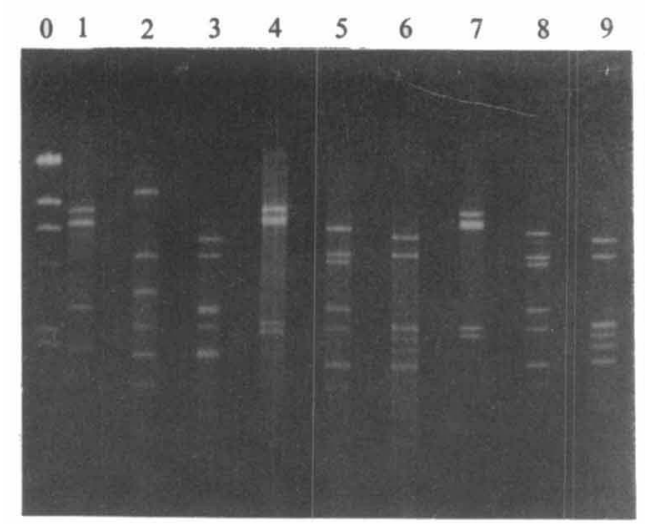

(b)

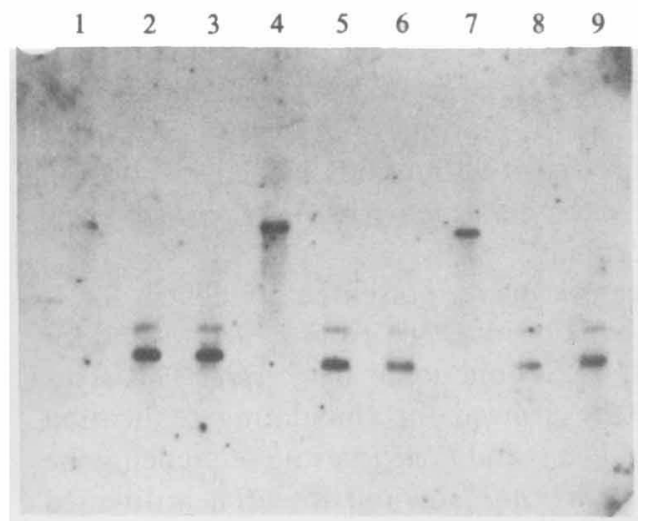

Fig. 7. Agarose gel electrophoresis of restriction enzyme digested mt DNA fragments from $P$. urticae and $P$. chrysogenum (a) and Southern hybridization analysis with large $\mathrm{mt} \mathrm{rRNA}$ as a probe $(b)$. Purification and labelling of large mt rRNA were similar to those of small mt rRNA (see Fig. 6). Panel (a) is identical to Fig. 6(a). The nylon membrane after hybridization with the labelled small mt rRNA was washed and reused for hybridization with large mt rRNA as a probe (b). The second band in lane $a-1$ (E2 and/or E3) is weakly hybridized (lane $b$-1). However, when the experiment was repeated, it was strongly hybridized.

were confined to the $6 \cdot 3 \mathrm{~kb}$ region $(\mathrm{H} 4-\mathrm{H} 6)$ in $P$. urticae (Fig. 2, I) and to the $5.8 \mathrm{~kb}$ region $(\mathrm{H} 5-\mathrm{H} 7)$ in $P$. chrysogenum (Fig. 2, II). These results indicate that the large and small $\mathrm{mt}$ rRNA genes of $P$. urticae are located in a similar region and support the above conclusion of the similar genome arrangement of mt DNA in P. urticae and $P$. chrysogenum. The minimal distance between the two mt rRNA genes was $1.36 \mathrm{~kb}$ for $P$. urticae and $1.25 \mathrm{~kb}$ for $P$. chrysogenum, whereas the distance was $3.1 \mathrm{~kb}$ for $A$. nidulans (Netzker et al., 1982).

\section{Discussion}

Fungal mitochondrial genomes vary in length between $18.9 \mathrm{~kb}$ and $121 \mathrm{~kb}$ (Grossman \& Hudspeth, 1985). In the genus Aspergillus, wide variation of the mitochondrial genome size ( 26 to $42 \mathrm{~kb}$ ) was estimated from the sum of the restriction fragment sizes (Kozłowski \& Stepień, 1982). In $P$. chrysogenum, previous reports indicated that the genome sizes of mt DNA were $32 \cdot 2 \mathrm{MDa}(49 \mathrm{~kb})$ for strain NRRL 1951 and $27 \cdot 1 \mathrm{~kb}$ for strain BC2, and the restriction enzyme pattern was quite different between these strains (Smith et al., 1984; Stahl et al., 1987). However, our results indicated similarities in size and restriction map of mt DNA between $P$. chrysogenum BC2, and $P$. chrysogenum NRRL 1951 and IAM 7119 (Fig. 2), and the latter two genomes were identical in restriction map and genome order (Figs 2, 6 and 7). Since our cleavage pattern of mt DNA of $\boldsymbol{P}$. chrysogenum 1951 was very clear (Figs 6 and 7), the conflicting result by Smith et al. (1984) might have been caused by their crude mt DNA preparations and/or incomplete digestion.
Comparison of mitochondrial genomes between $P$. urticae and $P$. chrysogenum indicated similar genome sizes and arrangements, including locations of rRNA genes and ARSs (Figs 3, 4, 6 and 7).

$P$. urticae and $P$. chrysogenum had common sizes of cytosol rRNAs, which were also similar to those of $S$. cerevisiae (Fig. 5). For mt rRNA, the size of the small subunit from $P$. urticae was also similar to those from $P$. chrysogenum (Fig. 5) and A. nidulans (1.55 kb; Dyson $e t$ al., 1989), but smaller than those from $S$. cerevisiae $(1.7 \mathrm{~kb}$; Li et al., 1982) and $N$. crassa $(2.0 \mathrm{~kb}$; Mannella et al., 1979; Green et al., 1981). In spite of the extensive homology of the mt DNAs and the small subunits of rRNAs between $P$. urticae and $P$. chrysogenum (Figs 2 and 5), the large subunit of mt rRNA was markedly different in size $(4.2 \mathrm{~kb}$ for $P$. urticae and $3.5 \mathrm{~kb}$ for $P$. chrysogenum) (Fig. 5). The large subunit in $P$. urticae mitochondria was $1.1 \mathrm{~kb}$ larger than that in the closely related fungi $A$. nidulans (Dyson et al., 1989) and $N$. crassa (Green et al., 1981), 0.8-0.9 kb larger than that in S. cerevisiae (Dujon, 1980; Sor \& Fukuhara, 1983) and at least $0.5 \mathrm{~kb}$ larger than those in plants (Leaver \& Gray, 1982; Falconet et al., 1985). The $4.2 \mathrm{~kb}$ size of the large mt rRNA in $P$. urticae is, to our knowledge, the largest that has ever been described for mt rRNAs. The markedly larger size was not caused by the mutation of the wild-type $P$. urticae NRRL 2159 to the albino NRRL 2159A, since their mt rRNAs migrated similar distances on agarose/formaldehyde gel electrophoresis (data not shown).

The size difference of mt rRNA may be caused by a nuclear mutation. Splicing is well known in the large 
subunits of mt rRNAs from yeasts and fungi (Merten et al., 1980; Mahler, 1983) and nuclear mutations have been found to lead to a deficiency in splicing and accurrulation of novel larger-sized precursor rRNAs (Miduelia ct al., 1979; Garriga et al., 1984). However, these temperature-sensitive mutants lacked respiration at ncu-permissive temperatures, whereas $P$. urticae grew and respired normally.

Is this paper we have presented evidence for a complete clone bank of mt DNA from $P$. urticae and for the presence of ARSs functional in $S$. cerevisiae. This clone bank will be utilized for elucidating replication functions in $A$. nidulans and $P$. urticae and sequencing the rRNA gene of $P$ urticae. Now our research is directed toward the spilicing mechanism of large subunits of $\mathrm{mt}$ rRNAs from $P$. urticae and $P$. chrysogenum.

We authors wish to thank Dr Y. Horibe, Kotobuki Pharmaceutical Conpary, for the use of a Hitacini HUS-5 evaporator and Dr M. Nakagaki for the help in the election microscepy. They atso thank Dr S. W Feterson, Northorm Regional Research Center, United States Department of Agriculture, and the curater of the Microbial Stock Lahoratory, Institute of Applied Microbiology. Tokyo Iniversity, for gifts of $P$. chrusogenum NRRL. i951 and IAM 7119, respectively. They also thank Dr. H. Moriyama, Kumamoto Institute of Technology for sharing his unpuovished data

\section{References}

Botstein, D., Falco, S. C., Stewart, S. E., Brennan, M., Scherer, S., Stinchсоmв, D. T., Struhl, K. \& Davis, R. W. (1979). Sterile host yeasts (SHY): a eukaryotic system of biological containment for recombinant DNA experiments. Gene 8, 17-24.

Cummings, D. J., Belcour, L. \& GrandChamp, C. (1979). Mitochondrial DNA from Podospora anserina. Molecular and General Genetics 171, 229-238.

DUjon, B. (1980). Sequence of the intron and flanking exons of the mitochondrial $21 \mathrm{~S}$ rRNA gene of yeast strains having different alleles at the omega and rib-l loci. Cell 20, 185-197.

Dyson, N. J., Brown, T. A., Waring, R. B. \& Davies, R. W. (1989). The mitochondrial ribosomal RNA molecules of Aspergillus nidulans. Gene 75, 109-118.

Falconet, D., Delorme, S., Lejeune, B., Sévignac, M., Delcher, E., BAzETOUX, S. \& QuÉTIER, F. (1985). Wheat mitochondrial 26S ribosomal RNA gene has no intron and is present in multiple copies arising by recombination. Current Genetics 9, 169-174.

GARRIGA, G. \& LAMBOWITZ, A. M. (1984). RNA splicing in Neurospora mitochondria: self-splicing of a mitochondrial intron in vitro. Cell 38 , 631-641.

Garriga, G., Bertrand, H. \& Lambowitz, A. M. (1984). RNA splicing in Neurospora mitochondria: nuclear mutants defective in both splicing and 3 ' end synthesis of the large rRNA. Cell 36, 623634.

Georgiev, O. I., Nixolaev, N., Hadjolov, A. A., Skryabin, K. G., ZAKHARYEV, V. M. \& BAYEV, A. A. (1981). The structure of the yeast ribosomal RNA genes. 4. Complete sequence of the 25S rRNA gene from Saccharomyces cerevisiae. Nucleic Acids Research 9, 6953-6958.

Green, M. R., Grimm, M. F., Goewert, R. R., Collins, R. A., Cole, M. D., Lambowitz, A. M., Heckman, J. E., Yin, S. \& RajBhanDARY, U. L. (1981). Transcripts and processing patterns for the ribosomal RNA and transfer RNA region of Neurospora crassa mitochondrial DNA. Journal of Biological Chemistry 256, 2027-2034.

Grossman, L. I. \& Hudspeth, M. E. S. (1985). Fungal mitochondrial genomes. In Gene Manipulations in Fungi, pp. 65-103. Edited by J. W. Bennett \& L. L. Lasure. London: Academic Press.
HOFFMAN, C. S \& WINSTON. F. (1987). A ten-minute DN A preparation from yeast efficiently releases autonomous plasmids for transformation of Escherichia coli. Gene 57, 267-272.

Ito, H., Fukuda, Y., Murata, K. \& Kimura, A. (1983). Transformation of intact yeast cells treated with alkali cations: Journal of Bacteriology 153, 163-168.

KÖCHEL, H. G. \& KÜNTZEL, H. (1981). Nucleotide sequence of the Aspergillus nidulans mitochondrial gene coding for the smail ribosomal subunit RNA: homology to E. coli $16 \mathrm{~S}$ rRNA. Nucleic Acids Research 9, 5689-5696.

KöCHEL, H. G. \& KÜNTZEL, H. (1982). Mitochondrial L-rRNA from Aspergillus nidulans: potential secondary structure and evolution. Nucleic Acids Research 10, 4795-4801.

Kozıowski, M. \& STEPIEŃ, P. P. (1982). Restriction enzyme anaiysis of mitochondrial DNA of members of the genus Aspergillus as an aid in taxonomy. Journal of General Microbiology 128, 471-476.

LAMBOWITZ, A. M. (1989). Infectious introns. Cell 56, 323-326

LANG, D. \& MitaNi, M. (1970). Simplified quantitative electron microscopy of biopolymers. Biopolvmers 9, 373-379.

Leaver, C. J. \& Gray, M. W. (1982). Mitochondrial genome organization and expression in higher plants. Annual Review of Plant Phisiology 33, 373-402.

LFHRaCh, H., Diamond. D., WozNey, J. M. \& BoedtKer, H. (1977). RNA molecular weight determinations by gel electrophoresis under denaturing conditions, a critical reexamination Biochemistry 16 $47.5745 \mathrm{i}$

Li, M, TZagolore, A, UNDererink-Lyon, K. \& Martin, N. C (1982). Identification of the paromomycin-resistance mutation in the $15 \mathrm{~S}$ rRNA gene of yeast mitolendria. Journal of Biological Chemisto 257, 59215928.

MAHLer, H. R. (1983). The exon introni structure of some mitochondrial genes and its relation to mitochondrial evolution. International Reriew of Cytology 82, 1 98.

Maniais, T., Fritsch, E. F \& Sambrook, J. (1982). Molecular Cloning, a Laboratory Manual. Cold Spring Harbor, NY: Cold Spring Harbor Laboratory.

Mannella, C. A., Collins, R. A., Green, M. R. \& Lambowitz, A. M. (1979). Defective splicing of mitochondrial rRNA in cytochromedeficient nuclear mutants of Neurospora crassa. Proceedings of the National Academy of Sciences of the United States of America 76, 2635-2639.

MaNTle, P. G. (1987). Secondary metabolites of Penicillium and Acremonium. In Penicillium and Acremonium (Biotechnology Handbook vol. 1), pp. 161-243. Edited by J..F. Peberdy. New York: Plenum Press.

MAXAM, A. M. \& GilberT, W. (1980). Sequencing end-labeled DNA with base-specific chemical cleavages. Methods in Enzymology 65, 499-560.

Merten, S., Synenki, R. M., Jocker, J., Christianson, T. \& RABINOWITZ, M. (1980). Processing of precursors of $21 \mathrm{~S}$ ribosomal RNA from yeast mitochondria. Proceedings of the National Academy of Sciences of the United States of America 77, 1417-1421.

NetzKer, R., Kochel, H. G., Basak, N. \& KüNtzel, H. (1982). Nucleotide sequence of Aspergillus nidulans mitochondrial genes coding for ATPase subunit 6 , cytochrome oxidase subunit 3 , seven unidentified proteins, four tRNAs and L-rRNA. Nucleic Acids Research 10, 4783-4794.

Picknett, T. M., Saunders, G., Ford, P. \& Holt, G. (1987). Development of a gene transfer system for Penicillium chrysogenum. Current Genetics 12, 449-455.

Rubtsov, P. M., Musakhanov, M. M., Zakharyev, V. M., Krayev, A. S., Skr yabin, K. G. \& Bayev, A. A. (1980). The structure of the yeast ribosomal RNA genes. 1 . The complete nucleotide sequence of the $18 \mathrm{~S}$ ribosomal RNA gene from Saccharomyces cerevisiae. Nucleic Acids Research 8, 5779-5794.

SAunders, G. \& Holt, G. (1987). Genetics of the penicillia. In Penicillium and Acremonium (Biotechnology Handbook vol. 1), pp. 7391. Edited by J. F. Peberdy. New York: Plenum Press.

Saunders, G., Rogers, M. E., Adlard, M. W. \& Holt, G. (1984). Chromatographic resolution of nucleic acids extracted from Penicillium chrysogenum. Molecular and General Genetics 194, 343-345. 
Sekiguchi, J. \& Gaucher, G. M. (1977). Conidiogenesis and secondary metabolism in Penicillium urticae. Applied and Environmen tal Microbiology 33, 147-158.

SekiguCHI, J. \& GaUCHER, G. M. (1978). Identification of phyllostine as an intermediate of the patulin pathway in Penicillium urticae. Biochemistry 17, 1785-1791

Sekiguchi, J., Shimamoto, T., Yamada, Y.\& Gaucher, G M. (1983) Patulin biosynthesis: enzymatic and nonenzymatic transformations of the mycotoxin (E)-ascladiol. Applied and Encironmental Microblology 45, 1939-1942.

Sharp, P. A., Sugden, B. \& Samarock. J (1973). Detecticr of two restriction endonuclease activities in Haemophilus parcintiuenzac using analytical agarose-ethidium bromide electrophoresis sic ht $m$. istry 12, 3055--3063.

SILhaVy, T. J., Berman, M. L. \& ENQUist, L. W. (i984). Eneriments with Gene Fusions. Cold Spting Harbor, NY: Cold Srring Hattor Laboratory

Smith, T. M., Salnders, G., Stacey, L. M. \& HClt, G (984) Restriction endonuclease map of mitochondrial DNA from Penicillium chrvsogenum. Journal of Botechrology 1, 37. 46.

SOR, F \& FuklHara. H. (1983), Complete DNA sequence coding for the large ribosomal RNA of yeast mitochondria. Nucleic Acids Research 11, 339-348.

SOUTHERN, E. M. (1975). Detection of specific sequences among DNA fragments separated by gel electrophoresis. Journal of Molecular Biology 98, $503.51 \%$
STAHL, U., LeitNer, F. \& ESSER, K. (1987). Transformation of Penicilium chrysogenum by a vector contaning a mitochoncial origin of replication. Afplied Microbiolog: and Putechnilogy 26, 237 241

STEFEN, P. P., BERNARD, POCKE, If \& KCNTZRI, H (1978) Restriction endonuclease ieavage mat of niwochondrial DNA from Aspergillus nidularis. Nucleic Acids Rescirth $5,3: 7-330$

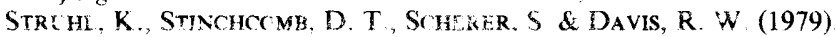
High frequency transfermation of yeast: antonomous replication of hybrid DNA molecules Procedings of the National Academy of Sriences of the rited Siates of America \%6, 1035-1039.

TeTzYNSK, F \& CASiR, K (985). Mitochondrial DNA for gene clenng in sukaryotes 1ri Gene fanipuiations in Fungi, pp. 403-416. Edited by W. Bennert \& L. L I : 3 sure. Iondon: Academic Press.

WRICHT, R. M. L LPING, I I. HGRRUM M. A. \& CUMmINGS, D. J.

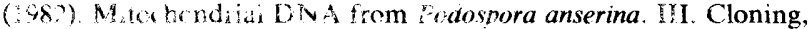
physicai mapling, anc lecaization of he ribosomal RNA genes. Molectalor atd Gonerai Generics 185. 56-64.

Yaivisch. Períon, C. Vietra, J. \& Messing, J (1985). Improved M13 phage cloning vectors and host strains: nucleotide sequences of the M13mpl8 and pUC19 vectors. Gene 33, 103-119.

ZAMIR, L. O. (1980). The biosynthesis of patuíin and penicillic acid. In The Biosynthesis of Mycotoxins, pp. 223-268. Edited by P. S. Steyn. New York: Academic Press. 